\title{
Investigasi Hubungan Keragaman Gen Leptin Receptor (LEPR) dengan Karakteristik Karkas dan Kualitas Daging Domba
}

\author{
Investigation of Leptin Receptor (LEPR) Gene Polymorphism and Association with Carcass Characteristic \\ and Meat Quality in Sheep
}

D. Azizah, R. R. Noor, \& A. Gunawan*

Departemen Ilmu Produksi dan Teknologi Peternakan, Fakultas Peternakan, IPB University

Jl. Agatis, Kampus IPB Darmaga Bogor 16680, Indonesia

*Corresponding author: agunawan@apps.ipb.ac.id

(Received 29-06-2020; Revised 23-07-2020; Accepted 10-08-2020)

\begin{abstract}
Improvement of meat quality plays important role for sheep meat producer and costumer market. Leptin Receptor (LEPR) gene is speculated has important role in carcass and meat quality. This study aims to investigate the relationship between the LEPR gene variation with characteristics of carcass and meat quality in sheep. A total 50 rams consisted 20 of Javanese fat tailed (JFT), 10 of garut composite (GCS), 10 of compass agrinak (CAS), and 10 of barbados cross (BCS) were used in this study. Polymorphism of LEPR gene were performed by Polymerase Chain Reaction-Restriction Fragment Length Polymorphism (PCR-RFLP) with Acil as restriction enzyme. The results showed that of the amplification product was $432 \mathrm{bp}$. The result of polymorphism of LEPR gene were polymorphic with third genotype including AA, AC, dan CC. The SNP of LEPR gene with genotype AA was associated $(P<0.05)$ with carcass characteristics including empty body weight, cold carcass and with genotype $\mathrm{AC}$ on meat quality including tenderness. It could be concluded that the SNP g.40854778 A $>C$ of LEPR gene may contribute to the characterictic carcass and meat quality in sheep.
\end{abstract}

Keywords: characteristic carcass, LEPR gene, meat quality, PCR-RFLP, sheep.

\section{ABSTRAK}

Peningkatan kualitas daging memiliki peran penting untuk produsen dan konsumen daging domba. Gen Leptin Receptor (LEPR) diduga memiliki peran penting terhadap karakteristik karkas dan kualitas daging. Penelitian ini bertujuan untuk mengidentifikasi hubungan keragaman gen LEPR dengan karakteristik karkas dan kualitas daging pada domba. Total sampel yang digunakan adalah 50 ekor domba jantan yang terdiri atas 20 ekor domba ekor gemuk (DEG), 10 ekor domba komposit garut (DKG), 10 ekor domba compass agrinak (DCA), dan 10 ekor domba barbados cross (DBC). Polimorfisme gen LEPR di analisis menggunakan Polymerase Chain Reaction-Restriction Fragment Lenght Polymorphism (PCR-RFLP) dengan Acil sebagai enzim restriksi. Hasil dari produk amplifikasi sepanjang 432 bp. Hasil keragaman gen LEPR yang didapat bersifat polimorfik dengan 3 genotipe yaitu AA, AC, dan CC. SNP gen LEPR dengan genotipe AA berasosiasi $(\mathbf{P}<\mathbf{0 . 0 5})$ dengan karakteristik karkas yaitu bobot tubuh kosong dan karkas dingin serta dengan genotipe AC pada kualitas daging yaitu keempukan. SNP pada posisi g.40854778 A>C gen LEPR disimpulkan berkontribusi pada karakteristik karkas dan kualitas daging domba.

Kata kunci: domba, gen LEPR, karakteristik karkas, kualitas daging, PCR-RFLP. 


\section{PENDAHULUAN}

Daging merupakan produk utama yang dihasilkan pada usaha ternak potong. Salah satu ternak potong yang berkontribusi terhadap produksi daging nasional yaitu ternak domba. Domba termasuk salah satu ternak ruminansia yang berperan penting dalam pemenuhan protein hewani masyarakat. Peningkatan karakteristik karkas dan kualitas daging sangat penting untuk pengembangan pasar daging domba. Selain itu, telah dilaporkan bahwa konsumen daging siap membayar lebih dua atau tiga kali untuk kualitas daging yang lebih baik (Lyford et al. 2010).

Kualitas daging merupakan sifat kuantitatif yang dikontrol oleh banyak pasang gen (poligenik). Salah satu gen yang diduga berperan terhadap karakteristik karkas dan kualitas daging adalah gen Leptin Receptor (LEPR). Mutasi pada gen LEPR telah diasosiasikan dengan ciri-ciri yang berhubungan dengan penumpukan lemak seperti ketebalan lemak punggung, kadar lemak, kadar lemak intramuskuler dan rata-rata bobot badan harian (Kovacik et al. 2011; Munoz et al. 2011; Perez et al. 2012).

Gen LEPR memiliki peran penting dalam regulasi metabolisme lemak dan termasuk family reseptor sitokin tipe I. Gen LEPR terdapat di olfactory bulb dan piriform cortex (Benner et al. 1998). Leptin bekerja dengan menghambat jalur orexigenic (merangsang nafsu makan) dan merangsang jalur anorexigenic (menekan nafsu makan) melalui reseptornya di hipotalamus (Bell et al. 2005).

Keragaman genetik gen LEPR dilaporkan berasosiasi dengan kualitas sifat perlemakan, odour dan flavour pada daging domba. Gunawan et al. (2018) melaporkan bahwa Single Nucleotide Polymorphism (SNP) pada posisi g.40854778 A $>$ C gen LEPR memiliki hubungan yang signifikan dengan asam lemak jenuh termasuk asam trikosanoat (C23:0), asam tetrakosanoat (C24:0), dan asam lemak tak jenuh jamak asam dekosaheksaenoat (C22:6n3). Namun, gen LEPR (g.40854778A>C) tidak memiliki efek signifikan dengan odour dan flavour daging domba.

Keragaman genetik gen LEPR dilaporkan secara nyata berhubungan dengan kualitas karkas dan daging babi (Amills et al., 2008; Kuehn et al., 2009; Uemoto et al. 2012; Mackowski et al. 2005). Diketahui sekitar 25 SNP LEPR telah diidentifikasi terkait dengan sifat-sifat kualitas daging dengan breed yang spesifik yaitu babi Duroc (Uemoto et al. 2012), Landrace Polandia (Mackowski et al. 2005), Yorkshire x Landrace cross (Kuehn et al. 2009) dan Landrace (Amills et al. 2008). Namun, keragaman gen LEPR belum pernah dilaporkan berhubungan dengan karakteristik karkas dan kualitas daging domba.

Penelitian ini dilakukan untuk mengidentifikasi keragaman gen Leptin Receptor (LEPR) dan kaitannya dengan karakteristik karkas dan kualitas daging domba dengan menggunakan teknik PCR-RFLP (Polymerase Chain Reaction-Restriction Fragment Length Polymorphism).

\section{MATERI DAN METODE}

\section{Waktu dan Lokasi Penelitian}

Penelitian ini dilaksanakan di Laboratorium Genetika Molekuler Ternak dan Laboratorium Ruminansia Kecil dan Ruminansia Besar, Departemen Ilmu Produksi dan Teknologi Peternakan, Fakultas Peternakan, Institut Pertanian Bogor pada bulan Oktober sampai Desember 2019.

\section{Ternak dan Sampel Penelitian}

Ternak yang digunakan pada penelitian ini adalah domba jantan sebanyak 50 ekor yang terdiri dari domba ekor gemuk (DEG) 20 ekor, domba komposit garut (DKG) 10 ekor, domba compass agrinak (DCA) 10 ekor, dan domba barbados cross (DBC) 10 ekor yang berasal dari Pusat Penelitian dan Pengembangan Peternakan (Puslitbangnak). Domba yang digunakan berumur 10-12 bulan dengan bobot 20-25 kg. Pemotongan domba dilakukan di Laboratorium Ruminansia Kecil sedangkan penanganan karkas di Laboratorium Ruminansia Besar, Institut Pertanian Bogor. Data karakteristik karkas dan kualitas daging yang diamati mengacu pada Gunawan et al. (2019). Sampel daging domba yang digunakan untuk ekstraksi DNA adalah bagian loin.

\section{Prosedur Penelitian}

\section{Pengukuran karakteristik karkas dan kualitas daging}

Karakteristik karkas yang diamati adalah bobot hidup, bobot tubuh kosong, karkas hangat, persentase karkas, panjang karkas, dreesing percentage, dan karkas dingin. Parameter yang digunakan untuk mengukur kualitas daging adalah susut masak, $\mathrm{pH}$ daging, dan keempukan. Susut masak diukur dengan berat awal sampel daging dikurangi dengan berat sampel daging setelah direbus dalam air pada suhu $80{ }^{\circ} \mathrm{C}$ dengan thermometer bimetal. Tingkat keempukan daging dapat diukur setelah selama 24 jam postmortem ( $\mathrm{pH}$ ultimate) sampel daging dilayukan dan diukur melalui besarnya kekuatan $\left(\mathrm{kg} \mathrm{cm}^{-2}\right)$ yang ditunjukkan jarum WBSF untuk memotong core daging. $\mathrm{pH}$ daging diukur dengan menggunakan $\mathrm{pH}$ meter setelah daging dilayukan selama 24 jam postmortem ( $\mathrm{pH}$ ultimate).

\section{SNP LEPR}

Target SNP gen LEPR yang digunakan pada penelitian ini mengacu pada Gunawan et al. (2018). Posisi SNP gen LEPR pada penelitian ini terletak di kromososm 1 intron 19 pada domba. Primer didesain dengan panjang sekuens 432 bp dengan sekuens primer sebagai berikut : Forward: 5'- GAT GAC CTG ACA TAT CCA GG -3' dan Reverse: 5'- CAA TGA AGT GGG GAA AGG AC-3'.

\section{Ekstraksi DNA}

Ekstraksi DNA diadaptasi dari metode ekstraksi Sambrook \& Russel (2001). Sampel daging domba digunakan untuk ekstraksi DNA sebanyak $50 \mathrm{mg}$. Sampel tersebut dimasukkan ke dalam tabung $1.5 \mathrm{~mL}$, ditambahkan $1000 \mu \mathrm{L}$ DW selanjutnya di vortex dan selama 5 menit didiamkan. Pada suhu $20{ }^{\circ} \mathrm{C}$, sampel disentrifuge dengan kecepatan $8000 \mathrm{rpm}$ selama 5 menit dan kemudian supernatan dibuang. Pada tabung $1.5 \mathrm{~mL}$ ditambahkan 350 
$\mu \mathrm{L} 1 \times$ STE, $10 \mu \mathrm{L}$ ProtK 5 mg mL-1, dan $40 \mu \mathrm{L}$ SDS 105, kemudian dikocok secara perlahan selama 2 jam dengan suhu $55^{\circ} \mathrm{C}$ di dalam inkubator. Kemudian, pada suhu ruang ditambahkan $400 \mu \mathrm{L}$ larutan fenol, $40 \mu \mathrm{L} \mathrm{NaCl} 5 \mathrm{M}$, dan 400 $\mu \mathrm{L}$ CIAA selama 1 jam dikocok pelan, selanjutnya selama 5 menit di sentrifuge dengan kecepatan $12000 \mathrm{rpm}$.

Supernatan atau larutan bening (bagian DNA) dipindahkan ke tabung $1.5 \mathrm{~mL}$ dengan mikropipet 1000 $\mu \mathrm{L}$. Kemudian ditambahkan $40 \mu \mathrm{L} \mathrm{NaCl} 5 \mathrm{M}$ dan 800 $\mu \mathrm{L}$ EtOH absolut dan dibekukan semalam dengan suhu -20 ${ }^{\circ} \mathrm{C}$, selanjutnya selama 5 menit disentrifuge dengan kecepatan $12000 \mathrm{rpm}$ pada suhu $20{ }^{\circ} \mathrm{C}$ dan dibuang bagian supernatannya. Kemudian ditambahkan $800 \mu \mathrm{L}$ EtOH 70\% dan disentrifuge pada suhu $20^{\circ} \mathrm{C}$ selama 5 menit dengan kecepatan $12000 \mathrm{rpm}$ dan bagian supernatannya dibuang lagi. Dalam keadaan terbuka, sampel didiamkan sampai alkohol hilang (mengering) dan ditambahkan Elution Buffer atau $100 \mu \mathrm{L}$ TE $80 \%$. Setelah itu, DNA disimpan dalam freezer suhu $-20{ }^{\circ} \mathrm{C}$ sampai akan digunakan.

\section{Amplifikasi DNA template dan pemotongan produk PCR}

Teknik PCR digunakan untuk mengamplifikasi DNA Template untuk menguji sampel domba yang diteliti. Sebanyak $0.1 \mu \mathrm{L}$ hasil ekstraksi sampel DNA dimasukkan ke dalam tabung PCR dan ditambahkan $14 \mu \mathrm{L}$ larutan premix (tersusun dari $06.3 \mu \mathrm{L}$ DW, $7.5 \mu \mathrm{L}$ Green Master Mix, dan $0.2 \mu \mathrm{L}$ primer). Campuran tersebut untuk proses amplifikasi diinkubasi dengan thermocycler. Denaturasi pada suhu $95{ }^{\circ} \mathrm{C}$ selama 5 menit merupakan tahap awal proses amplifikasi. Tahap kedua terdiri atas 35 siklus yang terdiri dari proses denaturasi selama 10 detik dengan suhu $95{ }^{\circ} \mathrm{C}$, annealing primer selama 20 detik pada suhu 60 ${ }^{\circ} \mathrm{C}$, dan ekstraksi DNA selama 30 detik pada suhu $72{ }^{\circ} \mathrm{C}$. Terakhir adalah tahapan pemanjangan primer pada suhu 72 ${ }^{\circ} \mathrm{C}$ selama 5 menit.

\section{Elektroforesis dan genotyping}

Amplikon dielektroforesis dipisahkan dengan menggunakan gel agarosa $1.5 \%$ yang terbuat dari $30 \mathrm{~mL}$ $0.5 \mathrm{xTBE}$ dan gel agarosa $0.45 \mathrm{~g}$ yang didalam microwave dipanaskan selama 3 menit dengan suhu medium-high. Kemudian, dilakukan homogenisasi dengan magnetic stirrer dan ditambahkan $1.8 \mu \mathrm{L}$ fluoro safe. Setelah itu gel dicetak dengan tray pencetak hingga mengeras. Sebanyak $5 \mu \mathrm{L}$ amplicon diambil dan dielektroforesis selama 25-35 menit dengan tegangan $100 \mathrm{~V}$ hingga fragmen DNA selesai migrasi pada gel. Hasil DNA yang telah selesai dielektroforesis dengan bantuan sinar UV dapat divisualisasikan.

Genotyping dilakukan dengan menggunakan enzim Acil yang memiliki situs pemotongan $(\mathrm{GGA} \mid \mathrm{G})$ dan dengan menggunakan teknik PCR-RFLP. Sebanyak $5 \mu \mathrm{L}$ amplikon ditambahkan dengan $0.7 \mu \mathrm{L}, 0.9 \mu \mathrm{L}$ buffer, dan $0.4 \mu \mathrm{L}$ enzim restriksi. Enzim Acil memotong gen LEPR selama 4 jam diinkubasi dengan suhu $37{ }^{\circ} \mathrm{C}$. DNA hasil pemotongan sebanyak $5 \mu \mathrm{L}$ dielektroforesis lagi selama 25-35 menit dengan tegangan $100 \mathrm{~V}$ pada gel agarosa 2 $\%$. Kemudian, sampel DNA hasil elektroforesis diangkat dan diamati di bawah sinar UV. Dari hasil elektroforesis, fragmen DNA yang muncul dibandingkan dengan marker untuk mengetahui panjang fragmennya.

\section{Analisis data}

Chi-Kuadrat digunakan untuk menguji keseimbangan Hardy-Weinberg (Hartl \& Clark, 1997). Rumus matematis yang digunakan adalah sebagai berikut:

$$
\chi^{2}=\Sigma \frac{(0-E)^{2}}{\mathrm{E}}
$$

Keterangan :

2: chi-kuadrat; O: nilai pengamatan; E: nilai harapan.

Hubungan antara genotipe gen LEPR dengan karakteristik karkas dan kualitas daging dianalisis dengan $\mathrm{Uji}-\mathrm{t}$ berpasangan. Model matematis yang digunakan sebagai berikut:

$$
t=\frac{\left(\overline{\mathrm{X}}_{1}-\overline{\mathrm{X}}_{2}\right)-\mathrm{D}_{\mathrm{D}}}{\delta^{2}\left(\frac{\sqrt{1}}{\mathrm{n}_{1}}+\frac{\sqrt{1}}{\mathrm{n}_{2}}\right)}
$$

\section{Keterangan :}

t: nilai thitung; dan : rataan kualitas daging atau karakteristik karkas dari genotipe 1 dan 2; n1 dan n2: jumlah individu genotipe 1 dan 2 ; : ragam gabungan.

\section{HASIL DAN PEMBAHASAN}

\section{Amplifikasi Gen LEPR $\mid$ Acil}

Amplifikasi gen Leptin Receptor (LEPR) dilakukan dengan menggunakan metode PCR pada sampel domba ekor gemuk (DEG), domba komposit garut (DKG), domba compass agrinak (DCA), dan domba barbados cross (DBC). Panjang produk PCR yang dihasilkan yaitu 432 bp. Keragaman gen LEPR diidentifikasi dengan metode PCRRFLP menggunakan enzim restriksi Acil yang memiliki situs pemotongan $(\mathrm{GGA} \mid \mathrm{G})$. PCR-RFLP merupakan suatu metode analisis lanjutan dari produk PCR. Hasil pemotongan oleh enzim restriksi Acil menghasilkan 2 alel yaitu A dan $\mathrm{C}$ dengan 3 genotipe yaitu AA, AC, dan CC. Genotipe AA memiliki 2 fragmen dengan panjang 292 bp dan 140 bp, genotipe AC memiliki 3 fragmen dengan panjang 432 bp, 292 bp, dan 140 bp, sedangkan genotipe CC memiliki 1 fragmen dengan panjang 432 bp. Perbedaan panjang fragmen pada penelitian ini menunjukkan bahwa adanya variasi pada sekuens gen LEPR. Gunawan et al. (2017) menyatakan bahwa keragaman DNA dapat terjadi akibat mutasi.

\section{Frekuensi Genotipe, Frekuensi Alel, dan Keseimbangan Gen dalam Populasi}

Nilai frekuensi genotipe gen LEPR yang tertinggi hingga terendah adalah AA, AC dan CC masing-masing sebesesar $0.65,0.30$ dan 0.05 . Hasil frekuensi genotipe, alel, dan keseimbangan Hardy-Weinberg gen LEPR pada domba DEG, DKG, DCA, dan DBC disajikan pada Tabel 1. Frekuensi genotipe gen LEPR yang didapat tidak berbeda jauh dengan hasil penelitian Pramukti (2018) yang menyatakan bahwa genotipe AA bernilai 0.66, genotipe AC bernilai 0.28 , dan genotipe $\mathrm{CC}$ bernilai 0.06 pada domba lokal. Keragaman genetik pada suatu populasi dapat terjadi 
Azizah et al.

Jurnal Ilmu Produksi dan Teknologi Hasil Peternakan 8 (3): 124-130

Tabel 1. Frekuensi genotipe, frekuensi alel dan keseimbangan Hardy-Weinberg pada domba DEG, DKG, DCA, dan DBC

\begin{tabular}{|c|c|c|c|c|c|c|c|c|}
\hline \multirow[t]{2}{*}{ Ternak Domba } & \multirow[t]{2}{*}{$\mathrm{N}$} & \multicolumn{3}{|c|}{ Frekuensi Genotipe } & \multicolumn{2}{|c|}{ Frekuensi Alel } & \multicolumn{2}{|c|}{$\begin{array}{l}\text { Keseimbangan } \\
\text { Hardy-Weinberg }\end{array}$} \\
\hline & & $\begin{array}{c}\text { AA } \\
(\mathrm{N}=34)\end{array}$ & $\begin{array}{c}\mathrm{AC} \\
(\mathrm{N}=14)\end{array}$ & $\begin{array}{c}\mathrm{CC} \\
(\mathrm{N}=2)\end{array}$ & A & $\mathrm{C}$ & $\mathrm{X}_{\text {hitung }}^{2}$ & $\begin{array}{l}\mathrm{X}^{2} \\
(0.05)\end{array}$ \\
\hline DEG & 20 & $\begin{array}{l}0.80 \\
(16)\end{array}$ & $\begin{array}{l}0.20 \\
(4)\end{array}$ & $\begin{array}{l}0.00 \\
(0)\end{array}$ & 0.90 & 0.10 & 0.24 & 3.84 \\
\hline DKG & 10 & $\begin{array}{l}0.40 \\
(4)\end{array}$ & $\begin{array}{l}0.50 \\
(5)\end{array}$ & $\begin{array}{l}0.10 \\
(1)\end{array}$ & 0.65 & 0.35 & 0.09 & 3.84 \\
\hline DCA & 10 & $\begin{array}{l}0.80 \\
(8)\end{array}$ & $\begin{array}{l}0.10 \\
(1)\end{array}$ & $\begin{array}{l}0.10 \\
(1)\end{array}$ & 0.85 & 0.15 & 3.69 & 3.84 \\
\hline DBC & 10 & $\begin{array}{l}0.60 \\
(6)\end{array}$ & $\begin{array}{l}0.40 \\
(4)\end{array}$ & $\begin{array}{l}0.00 \\
(0)\end{array}$ & 0.80 & 0.20 & 0.62 & 3.84 \\
\hline$\sum$ & 50 & $\begin{array}{l}0.65 \\
(34)\end{array}$ & $\begin{array}{l}0.30 \\
(14)\end{array}$ & $\begin{array}{l}0.05 \\
(2)\end{array}$ & 0.80 & 0.20 & & \\
\hline
\end{tabular}

$\mathrm{N}=$ banyak sampel, (..)=banyak sampel yang bergenotipe $\mathrm{AA}, \mathrm{AC}, \mathrm{CC}$

apabila terdapat dua alel atau lebih (lebih dari 1\%) (Nei \& Kumar 2000). Hasil penelitian ini menunjukkan bahwa keragaman gen LEPR pada DEG, DKG, DCA, dan DBC bersifat polimorfik atau beragam, karena ditemukan dua alel yaitu A dan C. Nilai frekuensi yang merupakan alel dominan adalah alel A yang berkisar 0.65-0.90. Gunawan et al. (2017) menambahkan bahwa keragaman genetik juga dapat terjadi apabila nilai frekuensi alel dan genotipe nya sama atau kurang dari 0.99 .

Populasi DEG, DKG, DCA, dan DBC berada pada keseimbangan Hardy-Weinberg. Hal ini karena $\mathrm{X}^{2}{ }_{\text {hitung }}$ yang didapat lebih kecil dibandingkan $\mathrm{X}_{\text {tabel, }}^{2}$, sesuai dengan pendapat Nei \& Kumar (2000) yang menyatakan bahwa jika hasil $\mathrm{X}_{\text {hitung }}^{2}$ lebih kecil dibandingkan $\mathrm{X}_{\text {tabel }}^{2}$ maka suatu populasi dapat dikatakan seimbang. Keseimbangan pada populasi domba yang diteliti karena jenis domba tersebut belum mengalami seleksi. Hal ini sesuai dengan Noor (2010) yang menyatakan bahwa ketidakseimbangan dapat terjadi apabila individu dalam populasi mengalami seleksi, migrasi, mutasi dan genetic drift.

\section{Asosiasi Keragaman Gen LEPR dengan Karakteristik Karkas DEG, DKG, DCA, dan DBC}

Hasil asosiasi gen LEPR pada posisi g.40854778A $>$ C dengan karakteristik karkas menunjukkan bahwa adanya hubungan yang signifikan $(\mathrm{P}<0.05)$ pada perbandingan genotipe AA dengan AC terhadap bobot badan tubuh dan karkas dingin pada populasi domba. Hasil asosiasi gen LEPR terhadap karakteristik karkas pada populasi domba disajikan pada Tabel 2.

Adanya hubungan antara gen LEPR dengan karakteristik karkas yaitu bobot tubuh kosong dan karkas dingin menunjukkan peran gen LEPR penting dalam mengontrol sifat kualitas karkas dan daging. Gen LEPR dianggap sebagai kandidat untuk sifat-sifat yang berkaitan dengan pertumbuhan dan komposisi badan. Penelitian Rodriguez et al. (2010) menemukan bahwa T alel pada gen LEPR berpengaruh terhadap bobot badan dan asupan pakan pada babi Duroc x Iberian. Penelitian Munoz et al. (2011) menyebutkan bahwa alel c.2002T pada gen LEPR meningkatkan bobot badan babi.

Tabel 2. Rataan nilai karakteristik karkas berdasarkan genotipe gen LEPR

\begin{tabular}{lcccccc}
\hline Karakteristik karkas & \multicolumn{3}{c}{ Genotipe } & \multicolumn{3}{c}{ P value } \\
\cline { 2 - 7 } & AA & AC & CC & AA vs AC & AA vs CC & AC vs CC \\
& $(\mathrm{N}=34)$ & $(\mathrm{N}=14)$ & $(\mathrm{N}=2)$ & & & \\
\hline Bobot hidup (kg) & $24.47 \pm 5.90$ & $23.45 \pm 6.37$ & $24.30 \pm 2.69$ & 0,611 & 0,949 & 0,761 \\
Bobot tubuh kosong (kg) & $18.51 \pm 7.35$ & $12.26 \pm 5.18$ & $9.30 \pm 0.00$ & $0.016^{*}$ & - & - \\
Karkas hangat (kg) & $10.07 \pm 3.72$ & $8.42 \pm 2.68$ & $8.12 \pm 1.23$ & 0,095 & 0,214 & 0,818 \\
Persentase karkas (\%) & $56.07 \pm 28.44$ & $42.91 \pm 23.40$ & $32.30 \pm 0.00$ & 0,272 & - & - \\
Panjang karkas (cm) & $85.60 \pm 18.54$ & $81.11 \pm 11.72$ & $91.00 \pm 29.7$ & 0,32 & 0,842 & 0,722 \\
Dressing percentage (\%) & $45.83 \pm 4.97$ & $41.40 \pm 0.00$ & - & - & - & - \\
Karkas dingin (kg) & $7.70 \pm 3.49$ & $4.76 \pm 0.69$ & $6.94 \pm 0.00$ & $0.002 *$ & - & - \\
\hline
\end{tabular}

$*=$ menunjukkan berbeda nyata $(\mathrm{P}<0.05)$ pada taraf $\alpha=0.05 ; \mathrm{N}=$ jumlah sampel 
Gol et al. (2015) menambahkan bahwa gen LEPR tidak hanya berpengaruh terhadap ketebalan lemak punggung dan lemak intramuskular tetapi juga berpengaruh terhadap bobot badan dan karkas pada babi. Penelitianpenelitian tersebut menunjukkan bahwa gen LEPR dapat meningkatkan asupan pakan dan menghasilkan babi dengan bobot badan yang lebih berat. Gen LEPR memberikan petunjuk untuk membuat protein yang disebut reseptor leptin, yang terlibat pada pengaturan bobot badan.

Beberapa mutasi gen LEPR dapat menyebabkan kekurangan reseptor leptin yang mencegah reseptor berikatan dengan leptin. Kekurangan reseptor leptin menyebabkan peningkatan asupan pakan dan meningkatkan bobot badan. Ovilo et al. (2005) menyatakan bahwa gen LEPR berpengaruh secara tidak langsung terhadap peningkatan asupan pakan, karena reseptor leptin bertindak sebagai perantara efek kenyang dari leptin. Leptin merupakan hormon protein yang disintesis dalam jaringan adiposa dan mempengaruhi asupan makanan, metabolisme lemak, dan beberapa fungsi reproduksi (Friedman 2002).

\section{Asosiasi Keragaman Gen LEPR dengan Kualitas Daging DEG, DKG, DCA, dan DBC}

Hasil analisis gen LEPR menunjukkan bahwa adanya asosiasi secara signifikan $(\mathrm{P}<0.05)$ terhadap keempukan daging domba. Hasil asosiasi gen LEPR dengan kualitas daging populasi domba disajikan pada Tabel 3. Gen LEPR diduga berhubungan dengan dengan keempukan daging. Hal ini sesuai dengan penelitian Balatsky et al. (2016) yang menyatakan bahwa gen LEPR berasosiasi secara signifikan dengan kadar lemak intramuskular dan keempukan daging pada babi Ukrainian Large White. Gen LEPR memiliki hubungan signifikan terhadap flavour dan keempukan pada pabi komersial (Canadian three-way cross) (Zhang et al. 2014).

Kualitas daging digunakan untuk menggambarkan setiap sifat yang berdampak pada penerimaan konsumen terhadap produk daging. Gen LEPR pada babi terletak di kromosom 6, daerah yang terkait dengan kadar lemak intramuskular, ketebalan lemak punggung, dan tingkat pertumbuhan ternak (Galve et al. 2012; Ovilo et al. 2000). Lemak intramuskular disebut marbling pada industri daging. Lemak intramuskular terletak diantara dan didalam serat otot (sel). Jumlah lemak intramuskular dan komposisi asam lemak memiliki peran utama dalam kualitas dari daging dan termasuk sifat sensorik seperti flavour, juiciness, dan keempukan daging. Thompson (2004) menyatakan bahwa peningkatan kandungan lemak intramuskular biasanya disertai dengan peningkatan keempukan, juiciness, dan flavour. Penelitian Gunawan et al. (2018) menemukan bahwa gen LEPR tidak berhubungan signifikan dengan odour dan flavour pada daging domba lokal.

Gen LEPR juga berhubungan dengan komposisi asam lemak di otot. Penelitian Gunawan et al. (2018) menemukan bahwa gen LEPR memiliki hubungan yang signifikan dengan asam lemak jenuh; asam trikosanoat (C23:0) dan asam tetrakosanoat (C24:0) dan asam lemak tak jenuh ganda; asam dekosaheksanoat (C22:6n3). Asam lemak berkontribusi terhadap berbagai aspek dari kualitas daging dan juga nilai gizi dari produk. Kandungan asam lemak jenuh dan asam lemak tak jenuh junggal yang dalam jumlah yang besar dapat meningkatkan flavour daging (Carrapiso et al. 2003; Burkett 2009). Asam lemak tak jenuh ganda dari sudut pandang gizi bermanfaat, tetapi dapat menyebabkan flavour yang tidak diinginkan hingga penurunan titik leleh lemak dan umur simpan daging yang lebih pendek (Wood et al. 2004). Hasil asosiasi gen LEPR terhadap sifat keempukan daging domba mengindikasikan bahwa gen LEPR memiliki potensi yang penting dalam menentukan kualitas keempukan daging domba.

Lingkungan juga berpengaruh terhadap karakteristik karkas dan kualitas daging. Fenotipe dapat digambarkan sebagai hasil dari interaksi antara genotipe dengan lingkungan (Peatson \& Whitelaw 2006). Noor (2010) menyatakan bahwa sifat pertumbuhan dan bobot badan dikendalikan oleh banyak gen (polygenes) dan sangat besar dipengaruhi oleh lingkungan. Pengaruh lingkungan terhadap kualitas daging paling baik didefinisikan karena tidak disebabkan oleh genetika dan termasuk peternakan, faktor penanganan sebelum pemotongan, dan setelah pemotongan (Warner et al. 2010). Faktor lingkungan pada penelitian ini telah seragam. Ternak yang diamati berasal dari Pusat Penelitian dan Pengembangan Peternakan (Puslitbangnak). Pemotongan domba dan penaganan karkas dilakukan di Laboratorium Ruminansia Kecil dan Ruminansia Besar, Institut Pertanian Bogor. Interaksi antara genetik dan lingkungan dapat menyebabkan suatu gen aktif pada suatu kondisi tertentu dan tidak aktif pada kondisi lainnya (Falconer \& Mackay 1996). Untuk memperoleh hasil yang lebih optimal sebaiknya dilakukan pengamatan pada lingkungan yang berbeda.

Tabel 3. Rataan nilai kualitas daging berdasarkan genotipe gen LEPR

\begin{tabular}{lcccccc}
\hline Kualitas daging & \multicolumn{3}{c}{ Genotipe } & \multicolumn{3}{c}{ P value } \\
\cline { 2 - 7 } & $\mathrm{AA}$ & $\mathrm{AC}$ & $\mathrm{CC}$ & AA vs AC & AA vs CC & AC vs CC \\
& $(\mathrm{N}=18)$ & $(\mathrm{N}=10)$ & $(\mathrm{N}=2)$ & & & \\
\hline $\mathrm{pH}$ & $6.25 \pm 0.31$ & $6.20 \pm 0.37$ & $6.03 \pm 0.12$ & 0.758 & 0.196 & 0.279 \\
Keempukkan $\left(\mathrm{kg} \mathrm{cm}^{-2}\right)$ & $3.48 \pm 0.95$ & $4.33 \pm 1.28$ & $3.30 \pm 0.28$ & 0.087 & 0.568 & $0.047^{*}$ \\
Susut masak (\%) & $43.87 \pm 8.43$ & $47.62 \pm 8.10$ & $44.15 \pm 12.47$ & 0.261 & 0.980 & 0.770 \\
\hline
\end{tabular}

$*=$ menunjukkan berbeda nyata $(\mathrm{P}<0.05)$ pada taraf $\alpha=0.05 ; \mathrm{N}=$ jumlah sampel 


\section{KESIMPULAN}

SNP g.40854778 A >C gen LEPR pada DEG, DKG, DCA, dan DBC bersifat polimorfik. Gen LEPR berasosiasi secara signifikan dengan karakteristik karkas yaitu bobot tubuh kosong dan karkas dingin serta kualitas daging yaitu keempukkan. Genotipe AA menghasilkan nilai karakteristik karkas yang lebih tinggi dibandingkan dengan genotipe AC dan genotipe AC menghasilkan nilai kualitas daging yang lebih tinggi dibandingkan dengan genotipe $\mathrm{CC}$.

\section{DAFTAR PUSTAKA}

Amills, M., D. Villalba, M. Tor, A. Mercadé., D. Gallardo., B. Cabrera., N. Jiménez., J. L. Noguera., A. Sànchez., \& J. Estany. 2008. Plasma leptin levels in pigs with different leptin and leptin receptor genotypes. J. Anim. Breed. And. Gene. 125(4):228-233.

Balatsky, V., I. Bankovska., R. N. Pena., A. Saienko., T. Buslyk., S. Korinnyi., \& O. Doran. 2016. Polymorphisms of the porcine cathepsins, growth hormone-releasing hormone and leptin receptor genes and their association with meat quality traits in Ukrainian Large White breed. J. Mol. Bio. Rep. 43(6):517-526.

Bell, C. G., A. J. Walley., \& P. Froguel. 2005. The genetics of human obesity. Nat. Rev. Genet. 6(3):221-234.

Benner, S. A., N. Trabesinger., \& D. Schreiber. 1998. Post-genomic science: Converting primary structure into physiological function. J. Adv. Enzyme. Regul. 38(1):155-180.

Burkett, J. L. 2009. The effect of selection for intramuscular fat on fatty acid composition in Duroc pigs. Thesis. Iowa State University, Iowa.

Carrapiso, A. I., F. Bonilla., \& C. García. 2003. Effect of crossbreeding and rearing system on sensory characteristics of Iberian ham. J. Meat. Sci. 65(1):623629.

Falconer, D. S. \& T. F. C. Mackay. 1996. Quantitative Genetics. 4th ed. Longman. Group. Ltd., Edinburgh.

Friedman, J. M. 2002. The function of leptin in nutrition, weight, and physiology. J. Nutr. Rev. 60(Suppl. 10):S1S14.

Galve, A., C. Burgos., L. Silió., L. Varona., C. Rodríguez., C. Ovilo., \& P. López-Buesa. 2012. The effects of leptin receptor (LEPR) and melanocortin-4 receptor (MC4R) polymorphisms on fat content, fat distribution and fat composition in a Duroc $\times$ Landrace/ Large White cross. J. Livest. Sci. 14(1-3):145-152.

Gol, S., R. Ros-Freixedes., M. Tor., R. N. Pena., M. F. Rothschild., \& J. Estany. 2015. Additive, dominant and epistatic effects of SCD and LEPR genes on fat content and fatty acid composition in pigs. AIDA. 483485 .

Gunawan, A., C. Sumantri., \& R. Juniarti. 2017. Gen dan Keragaman Genetik Ternak. Institut Pertanian Bogor (IPB)-Press, Bogor.

Gunawan, A., F. W. Pramukti., K. Listyarini., M. A. Abuzahra., Jakaria, C. Sumantri., I. Inounu., \& M.
J. Uddin. 2018. Novel variant in the leptin receptor (LEPR) gene and its association with fat quality, odour and flavour in sheep. JITAA. 44(1):1-9.

Gunawan, A., R. S. Harahap., K. Listyarini., C. Sumantri. 2019. Identifikasi keragaman gen DGAT1 serta asosiasinya terhadap karakteristik karkas dan sifat peternakan domba. JITRO. 6(2):259-266

Hartl, D. L. \& A. G. Clark. 1997. Principle of Population Genetic. Sinauer Associates, Sunderland.

Kovacik, A., J. Bulla., A. Trakovicka., Z. Lieskovska., \& J. Zitny. 2011. Effect of porcine LEPR polymorphism (Hpaii) on carcass traits in Large White A: Landrace Crossbred pigs. J. Anim. Sci. Biotechno. 44(1):260.

Kuehn, L. A., D. J. Nonneman., J. M. Klindt., \& T. H. Wise. 2009. Genetic relationships of body composition, serum leptin, and age at puberty in gilts. J. Anim. Sci. 87(2):477-483.

Lyford, C., J. Thompson., R. Polkinghorne, M. Miller., T. Nishimura., K. Neath., P. Allen., \& E. Belasco. 2010. Is willingness to pay (WTP) for beef quality grades affected by consumer demographics and meat consumption preferences. Australian. Agribusiness. Review. 18(1):1-17.

Mackowski, M., K. Szymoniak., M. Szydlowski., M. Kamyczek., R. Eckert., M. Rozycki., \& M. Switonski. 2005. Missense mutations in exon 4 of the porcine LEPR gene encoding extracellular domain and their association with fatness traits. J. Anim. Gene. 36(2):135-137.

Munoz, G., E. Alcazar., A. Fernandez., C. Barragan., A. Carrasco., E. de Pedro., L. Silio., J. L. Sanchez., \& M. C. Rodriguez. 2011. Effects of porcine MC4R and LEPR polymorphisms, gender and Duroc sire line on economic traits in Duroc $\mathrm{x}$ Iberian crossbred pigs. J. Meat. Sci. 88(1):169-173.

Nei, M. \& S. Kumar. 2000. Molecular Evolution and Phylogenetics. Oxford University-Press, New York.

Noor, R. R. 2010. Genetika Ternak. Penebar Swadaya, Jakarta.

Ovilo, C., A. Fernandez., J. L. Noguera., C. Barragan., R. Leton., C. Rodriquez., A. Mercade., E. Alves., J. M. Folch., \& L. Varona. 2005. Fine mapping of porcine chromosome 6 QTL and LEPR effects on body composition in multiple generations of an Iberian by Landrace intercross. J. Genet. Res. 85(1):57-67.

Ovilo, C., M. Perez-Enciso., C. Barragan., A. Clop., C. Rodriquez., M. A. Oliver., M. A. Toro., \& J. L. Noguera. 2000. A QTL for intramuscular fat and backfat thickness is located on porcine chromosome 6 . J. Mamm. Genome. 11(4):344-346.

Peatson, A., \& E. Whitelaw. 2006. Epigenetics and phenotypic variation in mammals. J. Mamm. Genome. 17(5):365-374.

Perez-Montarelo, D., A. Fernandez., J. M. Folch., R. N. Pena., C. Ovilo., \& C. Rodriguez. 2012. Joint effect of porcine leptin and leptin receptor polymorphisms on productivity and quality traits. J. Anim. Genet. 43(6):805-809.

Pramukti, F. W. 2018. Identifikasi keragaman gen leptin 
receptor (lepr) pada domba dan hubungannya dengan komposisi asam lemak daging. Skripsi. Institut Pertanian Bogor, Bogor.

Rodríguez, M. C., A. Fernández., C. Carrasco., A. García., E. Gómez., E. Mercado., M. A. López., C. Ovilo., \& L. Silió. 2010. Effect of LEPR c.2002C $>$ T SNP on feed intake and growth in heavy Duroc $\times$ Iberian crossbred pigs. 9th World Congress on Genetics Applied to Livestock Production (WGCALP), Lepzig, Germany.

Sambrook, J. \& D. W. Russel. 2001. Molecular Clonning A Laboratory Manual. Cold Spring Harbor Laboratory Press, New York.

Thompson, J. M. 2004. The effects of marbling on flavour and juiciness scores of cooked beef, after adjusting to a constant tenderness. Aust. J. Exp. Agr. 44(7):645-652.
Uemoto, Y., T. Kikuchi., H. Nakano., \& S. Sato. 2012. Effects of porcine leptin receptor gene polymorphisms on backfat thickness, fat area ratios by image analysis, and serum leptin concentrations in a Duroc purebred population. J. Anim. Sci. 83(5):375-385.

Warner, R. D., P. L. Greenwood., D. W. Pethick., D. M. Ferguson. 2010. Genetic and environment effects on meat quality. J. Meat. Sci. 86(1):171-183.

Wood, J. D., R. I. Richardson., G. R. Nute., A. V. Fisher., M. M. Campo., E. Kasapidou., P. R. Sheard., M. Enser. 2004. Effects of fatty acids on meat quality: a review. J. Meat. Sci. 66(1):21-32.

Zhang, C.Y., Z. Wang., H. L. Bruce., J.Janz., E. Goddard., S. Moore., \& G. S. Plastow. 2014. Associations between single nucleotide polymorphisms in 33 candidate genes and meat quality traits in commercial pigs. J. Anim. Genet. 45(4):508-516. 